\title{
ANO 2000 - 97 ANOS DO CENTRO ACADÊMICO XI DE AGOSTO
}

\section{Gauthama Carlos Colagrande Fornaciari de Paula}

Aluno do curso de Graduação da Faculdade de Direito da Universidade de São Paulo e membro do Conselho Editorial da Revista "O Onze de Agosto"

É ano 2000, último ano do século XX, e nele a mais antiga e notável entidade estudantil da América do Sul comemora 97 anos de uma existência brilhante, preenchida com os sonhos e ideais dos jovens aspirantes a bacharéis de São Paulo. Estes se organizaram sob a mesma bandeira em 1903, com o surgimento do Centro Acadêmico XI de Agosto. E é para contar alguns fatos marcantes desses 97 anos de história do XI de Agosto que se escreve o presente artigo.

Entre documentos antigos e publicações empoeiradas guardadas na estante reservada ao C.A. no Arquivo da Faculdade, foi possível encontrar registros valiosos da história acadêmica, cuja pesquisa foi útil para traçarmos um breve panorama histórico. Porém isso era pouco. Era preciso mais do que o simples contato com papéis: era preciso vivência.

Para tanto conversamos com Armando Marcondes Machado Jr., presidente do Centro Acadêmico XI de Agosto em 1952, o qual durante 11 anos debruçou-se na feitura de uma obra em cinco volumes contendo a história do Centro Acadêmico, listando todos os presidentes e diretores, bem como os grupos que disputaram as eleições. Além disso, o autor presta uma homenagem a todas as turmas de formandos das Arcadas, colocando o nome deles, do paraninfo, e o discurso do orador. A obra foi publicada em sua versão completa em 16 de Agosto de 1999, em encontro na Faculdade de Direito, havendo alunos formados desde 1934, além de uma banda de música. A entrevista que ora publicamos foi resultado dessa conversa, a qual motivou a presença das 19 últimas palavras deste trabalho.

A última parte deste trabalho foi reservada para contar com mais detalhes como foi a fundação do XI há 97 anos, e expor um pouco da história mais recente. 
Entrevista com Armando Marcondes Machado Jr.

Em que contexto surgiu o Centro Acadêmico XI de Agosto, e qual o papel que Pedro Dória teve na fundação do Centro Acadêmico?

Bom, durante um grande período (de 1870 à 1895), a freqüência na Faculdade era livre. Foi obrigatório desde a fundação da Faculdade, depois tornouse livre por força de um decreto imperial. Sendo livre, o aluno estudava em casa, e com isso não havia agrupamento de estudantes. No fim do século, como este sistema não podia dar certo mesmo, não havia convívio, decidiu-se extingui-lo. $\mathrm{O}$ contato com o professor era muito pequeno, o aluno vinha, requeria exame na matéria tal, fazia e ponto final. Era um estudante rico, estudava em casa, então não havia possibilidade de congregar os estudantes.

Quando se retomou a frequêencia obrigatória, obrigou o aluno a assistir à aula aqui, começando a existir uma participação do estudante. E aí aparece a figura do Pedro Dória, que sentiu a importância de reunir um grupo de estudantes. O Luís Pereira Campos Vergueiro que foi o segundo presidente, e o Macedo Soares que foi o terceiro, eles eram muito influentes e se juntaram. $O$ grupo todo dizia que "não, $o$ presidente tem de ser o Pedro Dória, porque o Pedro Dória é que é o nosso líder aqui, muito tranqüilo" Eu conheci o Pedro Dória, na época do cinqüentenário do Centro. Ele veio, e inauguramos a sede do Centro, no livro tem até uma fotografia. Pedro Dória era uma figura que se destacava e foi para o interior de São Paulo. Ele era alagoano de nascimento, mas advogou a vida toda no interior de São Paulo, foi um excelente advogado, um homem que redigia muito bem. Ele tinha uma liderança natural junto aos colegas, e a presença dele consolidou e permitiu o surgimento do XI de Agosto. E depois, seus sucessores também eram figuras interessantes: Luís Pereira Campos Vergueiro (1904) e o Macedo Soares (1905). O César Lacerda de Vergueiro, o quinto presidente, esse foi uma figura muito destacada. Ele deu bases sólidas ao XI de Agosto, porque ele comprou ações da Companhia Paulista de Estradas de Ferro. Foi quando o XI começou a ter patrimônio.

\section{Foi ele quem estabeleceu o patrimônio inalienável?}

Justamente, fizeram o patrimônio inalienável com as ações da Companhia Paulista de Estradas de Ferro. Quem começou isso foi o presidente de 1907. César Lacerda de Vergueiro, que veio a ser senador por São Paulo, e foi uma 
figura política de bastante destaque. Eu o conheci pessoalmente: um homem muito preocupado com o XI de Agosto. Todos os que assumiam o XI como presidente faziam campanha para a compra de ações. O Centro tinha bastantes ações. Depois, a Companhia Paulista foi privatizada e as ações tiveram de ser vendidas, e eu não sei o que aconteceu com esse dinheiro da venda das ações. Mas o XI de Agosto era acionista da Cia Paulista, a qual era a empresa mais importante do Estado de São Paulo. O XI ia às Assembléias da Companhia, era algo bem organizado. O Pedro Dória foi um elemento chave para consolidar o XI de Agosto. Foi a alma do XI nessa fase inicial. Uma curiosidade: foi a primeira vez que se colocou a iluminação para haver um evento, porque na Faculdade as aulas eram de manhã, não havia iluminação elétrica dentro do prédio. Iluminação elétrica no início do século era só na rua. Então, às pressas se fez uma iluminação para a solenidade que eles queriam fazer à noite. Então, os colunistas da época dizem pitorescamente o seguinte: "se de nada serviu o XI de Agosto, pelo menos para iluminar a Faculdade serviu!" Foi engraçado.

Ainda nessa fase inicial, existe no Arquivo da Faculdade muitos telegramas que o presidente do Centro Acadêmico enviava para o presidente da República, o qual respondia. Nota-se que desde cedo, a associação almejava influência com proporçôes. Qual foi o "impacto" do XI no país e no cotidiano paulistano nos primeiros anos?

Foi muito importante, porque os filhos das famílias mais importantes de São Paulo estudavam Direito. Filhos dos governadores, e de figuras da alta sociedade. São Paulo tinha uma participação muito grande na política, o Barão de Rio Branco estudou aqui. O estudante, filho dessas famílias ilustres, dava uma colaboração muito importante para a Faculdade. Eles eram da elite pensante, intelectuais, o pai dele era o ministro, o governador. Nesse contexto, o XI de Agosto tinha mesmo uma posição de destaque. Tanto é que, no Cerimonial do Palácio do Governo Estadual, o presidente do Centro Acadêmico tinha assento obrigatório na mesa principal. Se você verificar os arquivos, vai encontrar que, em 1911, houve um período que ocorreu uma duplicidade de comando. Irineu Forjaz foi eleito presidente, mas houve uma contestação, uma briga política, o grupo opositor era muito influente e entenderam que eles tinham ganho a eleição, e ficou uma coisa até engraçada, pois os dois se intitulavam presidente. Um que realmente foi eleito, e o outro que não se conformava. E o Governo do Estado precisou definir quem era, 
pois quando havia uma solenidade, os dois compareciam! Foi preciso o Governo se posicionar oficialmente e dizer que o presidente do Centro e que participaria do cerimonial era Irineu Forjaz, o qual fora eleito. Ficou engraçado. O Centro tinha uma posição de primeira linha perante a política local. Você há de imaginar que São Paulo era uma cidade pequena e o estudante de Direito tinha uma posição evidentemente muito maior do que tem hoje. Era um acontecimento dentro da cidade. Todos falavam do moço que estudava Direito. Esse primeiro período de existência do Centro Acadêmico, digamos os 25 primeiros anos, foi de uma posição bastante destacada do XI de Agosto, pela própria razão dos estudantes serem de famílias ilustres.

Nos primeiros anos, como foi a atuação do estudante e que fato marca o caráter do XI como defensor da Democracia?

No Centro Acadêmico em sua fase primeira, e mesmo depois, o estudante teve muita participação na política externa, ele fez, por exemplo, a luta do voto secreto; o voto secreto começou no XI de Agosto, antes o voto era aberto. A grande luta do estudante era para que o voto fosse secreto. Então, a primeira diretoria em que houve o voto secreto foi a de 1925, depois é que veio o voto secreto em 1932, na votação geral do país, mas o Centro foi um pioneiro no voto secreto. A mulher estudante votava, aí fora não votava. Perceba que o Centro sempre foi um grupo de vanguarda. Talvez hoje, o Centro tenha perdido essa característica de estar à frente, tanto no meio estudantil, quanto no geral, tomando posição, apontando pontos em que o Governo está mais desatento.

Falemos das campanhas realizadas pelo XI de Agosto, qual foi a primeira de grande repercussão?

O XI de Agosto teve campanhas muito bonitas, como essa do voto secreto, mas a primeira foi em 1910, a Campanha Civilista, ocorrida quando o Rui Barbosa foi candidato à Presidência da República. $O$ vice do Rui era o governador de São Paulo. O Rui era baiano, e o vice era o paulista Albuquerque Lins, que era advogado, mas não tinha estudado aqui. $O$ general Hermes da Fonseca era 0 candidato do governo, e o vice dele era o Wenceslau Braz, que era o governador de Minas. Então os dois vices eram o governador de São Paulo e o governador de Minas. Apesar do Rui ter grande votação nas capitais, já que ele era um grande 
orador, uma figura muito brilhante os alunos gostavam muito dele por ele ter estudado aqui, se identificava muito com o jovem, com o Direito, com essa mensagem bonita que o Direito leva como não podia deixar de ser, ele perdeu a eleição porque naquele tempo com a eleição à bico de pena o governo não perdia. Acabou perdendo e meteram na cabeça do Hermes da Fonseca que ele devia fazer uma intervenção em São Paulo pela petulância do governador de São Paulo ter feito chapa com o Rui, "onde já se viu, um governador do Estado de São Paulo, que depende do Governo Federal, se une com o Rui, um opositor ao governo Central?" Isso só não ocorreu porque os estudantes da Faculdade fizeram um tremendo dum movimento na rua e o Governo acabou ficando com medo, porque depois de uma campanha tão ardorosa que havia dado uma grande votação para o Rui, atingir a figura do governador de São Paulo, que era um advogado, que era uma sujeito que se identificava muito com o estudante e mexer com os companheiros do Rui seria uma coisa péssima para o presidente. A participação do estudante de Direito foi muito bonita e muito grande. Então esse era um episódio que amanhã deveria ser melhor trabalhado, eu não tive tempo de fazer um trabalho sobre isso porque é tanta coisa, a história da Faculdade se identifica tanto com a história de São Paulo, com a história do Brasil que não dá. A não ser que você pegue um tema específico. Só para complementar, a Campanha Civilista ocorreu exatamente quando Rui foi candidato pela primeira vez. O Rui depois foi candidato mais uma vez, porém com uma votação menor, contra Epitácio Pessoa. Detalhe, Rui Barbosa foi o único paraninfo sem ser professor até hoje, porque o paraninfo desde que a Faculdade existe foi um professor da Faculdade. Mas o Rui é uma exceção. Ele foi escolhido paraninfo não sendo professor, ele foi aluno. Ele não pôde vir porque estava doente, e o discurso dele, que é a famosa Oração aos Moços, foi lido pelo professor Reynaldo Porchat. Ele morava no Rio de Janeiro, e durante toda a sua vida advogou lá.

Em 1917, uma das grandes manifestações do Centro Acadêmico se deu com a criação da Liga Nacionalista. Esta teve por base a idéia lançada pelo poeta e jornalista Olavo Bilac e direcionada pelo professor Vergueiro Steidel, pela exaltação da nacionalidade, pelo serviço militar obrigatório, dada a instabilidade mundial. Além disso, a Liga Nacionalista demonstrava grande interesse numa reforma política, propondo o fim da fraude eleitoral. Como foi?

Nesse período, o Olavo Bilac esteve em São Paulo e a formação da Liga Nacionalista foi uma coisa muito importante, principalmente na Faculdade. 
Redundou no fato de o XI de Agosto começar o voto secreto. E foi muito interessante. Quando foi instituído o voto secreto, pela primeira vez a oposição ganhou por três votos as eleições para o XI de Agosto! Isso aconteceu em 1925, sendo o presidente Affonso Martins Ribeiro.

O estudante votava com o voto aberto, porque o estudante mais pobre precisava, por exemplo, para ser nomeado delegado de polícia (era tudo nomeado naquele tempo!), então a chance dele era estar bem com os poderosos. Quando veio o voto secreto, a oposição ganhou, e foi uma coisa espetacular! Daí o voto secreto irradiou-se do Largo para fora, passando a vigorar na política externa com o Código Eleitoral de 1932.

E o jornal $O$ Estado de $S$. Paulo teve grande participação com Júlio de Mesquita. Ele tem até uma cidade com o nome dele. Inclusive o Armando Sales, fundador da USP, era casado com uma filha do Júlio de Mesquita. É inegável essa luta da familia Mesquita nesses episódios.

Vejamos a atuação do Centro Acadêmico em 1930. Os estudantes ligados ao Partido Democrático (sucessor da Liga Nacionalista e antecessor remoto da UDN) apoiaram a Revolução Tenentista que levou, em 1930, Getúlio Vargas ao poder. Porém, Getúlio não democratizou o país e a Faculdade organizou um movimento cívico que resultou na Revolução Constitucionalista de 1932. Como foi esse periodo?

Em 1932, o movimento de alistamento, tudo se fazia aqui na Faculdade. $\mathrm{O}$ pátio era o local de recepção dos anéis oferecidos pelas famílias, com o fim de financiar a campanha. Formaram-se batalhões específicos de vários estudantes, e os que morreram nós temos seus nomes no monumento ao soldado de 32 no pátio, acompanhados dos inesquecíveis versos de Tobias Barreto:

\section{Quando se sente bater \\ No peito heróica pancada \\ Deixa-se a folha dobrada \\ Enquanto se vai morrer!}

Mas essa participação de 32 pela Constituição, pela consciência democrática, permitiu que em 34 houvesse uma primeira abertura. Fizeram a Constituição. O estudante teve uma participação muito bonita. Foi uma participação 
notável! Nós temos ali no pátio, no busto do Soldado Constitucionalista, os colegas que lutaram, e no meu livro eu transcrevo o trabalho de um desembargador, o qual narra a vida de um estudante que era estrangeiro, veio estudar na Faculdade e que foi combater em 32 por São Paulo, e morreu na Revolução.

Gostaria que o senhor comentasse o seguinte episódio ocorrido no Centro Acadêmico em 1938. Nesse ano, Getúlio Vargas estava vindo para São Paulo e era preciso que o Centro Acadêmico se posicionasse contra o presidente. Porém o presidente do Centro Acadêmico não se posicionava e na ocasião estava viajando. Então, raptaram o vice, e ficou sendo o presidente do XI o primeiro orador. Naquela época, a diretoria do XI era composta de membros de vários partidos pois, elegia-se nomes aos cargos...

Foi exatamente quando queriam dar a Getúlio o título de professor Honoris Causa pela Universidade de São Paulo. E houve um tremendo movimento dos estudantes contra. O Getúlio acabou declinando do título, porque ele não ia conseguir recebê-lo. Essa oposição a Getúlio vinha de 1932, dessa Constituição capenga que foi feita e que se alijava muito São Paulo. Que é uma coisa que foi até 45, quando ele foi deposto.

Fato de que nós não podemos nos esquecer foi o conflito dos estudantes com a polícia em julho de 1930, quando do assassinato de João Pessoa (companheiro de chapa da fracassada campanha de Vargas à presidência). Os estudantes promoveram uma passeata e a polícia reprimiu. Como o Largo era propriedade da União, o diretor convocou o exército, o qual chegou. A polícia e sua cavalaria recuou depois de uma batalha de muitos feridos e um soldado morto. Foi após esse episódio que o Centro Acadêmico, seguindo a proposta de Adriano Marrey, proclamou "Território Livre" o Largo de São Francisco.

Passados os anos da Ditadura do Estado Novo, a luta se deu então com a Campanha "O Petróleo é Nosso" Nessa época o senhor era o presidente do Centro Acadêmico, e percorreu várias cidades do interior de São Paulo, onde a delegação da São Francisco era recebida, com bandas e festejos...

A campanha foi maravilhosa. Na verdade a campanha começou antes. A luta pelo Petróleo começou em 1947. com Roberto Gusmão, que era o estudante presente no começo. Mas ela foi num crescendo, com o Roger Ferreira, em 1948, ela 
teve uma participação grande. Em 52 nós trouxemos aqui vários militares para fazer conferências, inclusive o pai do Fernando Henrique, Leônidas Cardoso, que era um general. Nos jornais nossos de 1952 tem a conferência dele, tem fotografia, tudo sobre a conferência do Leônidas Cardoso, que era um ardoroso nacionalista, e que naquele tempo preconizava a criação da Petrobrás, para o Brasil ter o controle da situação, porque o petróleo estava na mão das "Sete Irmãs" Então, foi uma campanha maravilhosa, com a presença de militares, de grandes oradores, especialistas abordando o tema, senadores, jornalistas. No livro eu tenho todas as datas em que cada conferência ocorreu. $\mathrm{O}$ povo vinha aqui para os debates da Faculdade, e a gente ia para a rua para fazer os comícios, com os grandes oradores que a gente tinha, o Almino Afonso (foi vice-governador de São Paulo e senador), o José Gregori (atual secretário de Diretos Humanos do Governo Federal). Foi vibrante porque o povo vinha na Sala dos Estudantes, e nós íamos para as ruas com os trabalhadores, os sindicatos. Tudo isso culminou, em 1953, na lei que criou a Petrobrás. O Getúlio era contra a criação da Petrobrás, mas a pressão popular foi tão grande, que a própria União Democrática Nacional acabou votando pela criação da Petrobrás, e o Getúlio acabou aceitando a lei do início do monopólio estatal. Eu sou ardorosamente a favor do monopólio e acho que instituições como a Petrobrás não podem ser vendidas. Você pode privatizar uma fábrica de parafusos, mas a Petrobrás não!

\section{Ainda mais depois de tanta luta para criá-la.}

Puxa! Foi uma luta. E. hoje, a Petrobrás é uma das maiores especialistas do mundo na extração de Petróleo na plataforma continental, na Bacia de Campos, no estado do Rio. Também nessa época houve um fato muito importante: a eleição para prefeito de São Paulo, o qual era nomeado. Então, nós fizemos também grandes movimentos na rua e acabou vindo a eleição direta, pelo voto popular. O resultado foi que Jânio Quadros tornou-se o primeiro prefeito a ser eleito. Eu estava terminando o meu mandato quando ocorreu a eleição do Jânio. E isso foi no início de 1953, naquele tempo tomava posse em março, era tradição. Esse episódio da autonomia de São Paulo que foi um avanço muito grande, sofreu uma interrupção no período militar. 
O Monteiro Lobato teve um papel preponderante nessa campanha "O Petróleo É Nosso" e fora membro do Centro Acadêmico em 1903 na comissão de redação. Como era o Monteiro Lobato nesses dois periodos?

O Monteiro Lobato foi da turma de 1904, aconteceu até um episódio interessante na formatura dele. Queriam que ele fosse orador da turma, mas ele era muito amigo do Edgar Jordão. Como ele era um rapaz muito destacado, lutou para que o Edgar Jordão fosse o orador. E o Edgar Jordão foi eleito o orador da turma, pela influência do Monteiro Lobato. E segundo consta, foi o Monteiro Lobato quem ajudou a escrever o discurso, deu uma "mãozinha" para o Edgar Jordão. E foi uma coisa inusitada porque o discurso - o qual eu transcrevo nessa edição de 5 volumes é muito avançado para a época: era um discurso socialista. E era tradição da Faculdade submeter o discurso ao diretor da escola, aí ele põe um visto apreciando, mas o diretor não se preocupou. Bom, esse discurso deu a maior confusão! Ele atacava a Igreja, tem uma linha socialista muito avançada... o arcebispo Dom José Gaspar, que estava presente na solenidade, se retirou quando ele viu que atacava a Igreja, e com ele a maioria dos professores se retirou. $\mathrm{E}$ apenas um professor ficou $\mathrm{e}$ disse ao aluno: "eu não concordo com o que você está dizendo, mas eu permaneço na reunião para você ter o direito de poder continuar" Ou seja, se o professor sai, encerra-se a sessão. E ficando um professor ele poderia continuar o discurso. Então, o professor foi muito distinto. O Edgar Jordão continuou lendo o discurso, mas com $80 \%$ das pessoas fora. Foi uma confusão tremenda, e dizem que aí tinha o dedo do Monteiro Lobato, o qual depois fez campanha pelo petróleo, foi preso, o DOPS tem uma documentação sobre Monteiro Lobato. Quando aluno, foi brilhante, ganhou um concurso de contos.

Aliás, foi Pedro Dória quem lembrou o nome dele para fazer parte da primeira Diretoria do XI?

Exato, ele era uma pessoa de destaque no meio estudantil, redigia muito bem. E depois, teve uma participação muito grande, tanto é que o primeiro poço de petróleo do Brasil é chamado de Lobato, em homenagem a ele, na Bahia.

Na época da campanha o Sr. realizou muitas viagens com o pessoal do Centro Acadêmico, e vocês iam para a praça da cidade e colocavam uma réplica de uma torre de petróleo... 
Sim, e aqui na frente da Faculdade ficava uma torre de petróleo, ficou vários anos, e se fazia muito comício. É uma pena que agora tenha uma tribuna no meio do Largo, e os alunos não façam nada. No livro, eu publico uma foto do Vicente Sampaio (presidente do XI em 53) discursando aqui na frente da Faculdade. O estudante contava com muito prestígio. O próprio Governo Federal, quando queria mexer com alguma coisa ligada ao estudante, solicitava a presença do presidente do XI de Agosto. Eu nunca fui porque o meu temperamento era mais retraído, e não queria ter contato com o Vargas, não era ligado à política do Vargas. Mas o Vicente fazia contatos, o Getúlio se preocupava demais com a posição do estudante de Direito de São Paulo. Ele tinha um temor, e precisava sentir se podia fazer isso, se podia fazer aquilo, então havia muito contato. Em 63 teve o contato com o João Goulart, foi um período muito brilhante, junto com o Orçalino Marçal (presidente do XI) que infelizmente faleceu. Ele disputou a eleição contra o Michel Temer (atual presidente da Câmara dos Deputados). Foi uma coisa linda, eu vim aqui para a Faculdade. O presidente da República veio aqui assistir à posse. Eu transcrevo no livro o discurso do Orçalino e o discurso do João Goulart de improviso. É uma pena a morte desse rapaz, esse moço não merecia morrer, um moço espetacular.

\section{Ele morreu como?}

Foi fazer uma operação, complicou e morreu na mesa de operação. Ele era filho de uma lavadeira, moço mulato e, por essa razão, o Jango sentiu que precisava prestigiar um jovem assim, que vinha de uma camada muito humilde, e que era presidente do XI de Agosto. O XI de Agosto, e o Jango sabia, por causa do Getúlio, dessa posição do estudante... então ele fez questão de vir. E veio junto com o Almino Afonso, que era ministro dele. Eu também exerci um cargo no Governo Federal, era presidente do IAPI, então eu vim. Só que eu não fiquei na mesa, eu preferi ficar sentado junto com os estudantes. Mas a participação dos estudantes em 64, esse movimento que depois redundou aí nessa desgraça que foi o período militar. João Miguel (presidente do XI em 64) esteve preso.

Além do Michel Temer, que outros nomes hoje famosos perderam a eleição para a Presidência do XI? 
Ah, o André Franco Montoro, que foi governador de São Paulo, eleito em 1983, além de ter sido parlamentar a vida inteira, praticamente a única eleição que perdeu na vida dele foi a de presidente do Centro Acadêmico. Também o Dalmo Dallari professor da Faculdade e que participa de comissões da ONU disputou o $\mathrm{XI}$, mas não conseguiu ganhar.

E o que o Sr. diz de 1954, da campanha pela renúncia do Getúlio Vargas e o posterior suicídio dele?

É, foi com o Vítor Fasano presidente. O Vítor Fasano era do Partido Libertador, porque em 1951, 52 e 53 foi o Partido Acadêmico Renovador que ganhou a eleição. Em 1954, nós perdemos a eleição.

Abrindo um parênteses, vale lembrar que naquela época havia uma disputa muito grande entre o Partido Acadêmico Libertador e o Partido Acadêmico Renovador, inclusive havia primárias...

As convenções do partido eram uma coisa fantástica! Cada partido fazia a sua convenção que, naquela época, nós chamávamos de prévia ou convenção, onde o partido tinha vários candidatos que disputavam a prévia. Era uma coisa acirradíssima... e o colega que ganhasse a convenção ia para a eleição final.

\section{E quem votava nessas prévias?}

Só os membros do partido votavam. O partido tinha uma ficha, e se eu tinha a ficha num partido, eu não tinha no outro, porque se ficava sabendo, e todo mundo sabia. Por isso só votava o integrante do partido. Nas prévias votavam alunos para "chuchu" porque a escola era dividida. Houve um período de prevalência do Renovador, depois do Libertador, com a diferenciação que o Renovador agrupava os comunistas e os grupos mais à esquerda. Às vezes, a gente tinha dificuldade de negociar com esses companheiros, que eram radicais. Seria hoje um PT, que tem aquele pessoal bem radical. Desse modo, a gente tinha uma conversação muito penosa às vezes, para manter agrupado, porque o estudante de esquerda é mais aguerrido, e acaba fazendo mais cisão. É mais belicoso. É diferente do conservador. Houve períodos fortes de crise do Renovador, por causa de agrupar esse monte esquerdizante. 
Mas não que isso fosse um defeito, havia dissensão, daí se enriquecia o debate. Porém tinha de agüentar muita provocação...

Exato, não é um impedimento, e minha nossa... o que se fazia de pichação aí era terrível! Os comunistas eram um grupo pequeno, de umas 50 pessoas, mas que eram pessoas que votavam com um pacto. E com efeito, uma eleição final era muito importante ter o apoio desses companheiros, que eram mais radicais, mas se agrupavam sob o manto do Renovador. Os partidos acadêmicos foram, de 1922 a 1968, uma grande escola política.

Desses partidos, o Partido Acadêmico Renovador foi muito peculiar, por ter entre seus fundadores, em 1945, vários integrantes da Força Expedicionária Brasileira. O partido teve 24 anos de existência, elegendo doze presidentes. Modéstia a parte, foi o mais significativo agrupamento estudantil da história do Centro. E por falar em FEB, é importante lembrar que a II Guerra Mundial levou 25 estudantes de Direito, em 1943, a combaterem na Itália, sendo que um deles, Fernando Corrêa da Rocha, foi piloto da Força Aérea; todos os demais integraram a FEB. Estes heróis foram homenageados numa placa de bronze colocada no hall de entrada da Faculdade.

Voltando ao assunto anterior, o Libertador era mais voltado contra 0 Getúlio. Então, quando entrou o Vítor Fasano, em 54, como ele era do Libertador, ah, não deu outra, eles fincaram pé nesse negócio contra o Getúlio. A linha do Fasano foi fortemente contra o Getúlio. Tinha esse caráter antigetulista. Como o Vicente, no ano anterior, que era do Renovador, dialogava com o Governo Federal, porque era importante o presidente do Centro manter um diálogo com o presidente da República, seja ele um ditador ou democrata. O Getúlio era um presidente eleito naquele momento. E o contato era com um ministro do Getúlio, o qual estabelecia comunicação com os estudantes, de maneira que esse ano de 1954 foi um ano terrivel, e o Renovador, por causa de uma dificuldade que o Vicente teve na sua Gestão, acabou tendo dois candidatos... virou uma situação complicada que não é conveniente eu abordar agora porque houve um episódio bastante triste. O Renovador perdeu a eleição devido a sua divisão, não porque o Libertador fosse forte. Mas o Renovador se dividiu e não houve possibilidade de acordo. E não foi um problema ligado aos comunistas não! Foi um outro tipo de problema, mas que separou o partido e eu já estava formado. Eu não tive participação nisso. E não houve jeito, a velha guarda do Renovador preferiu manter o nome de um candidato, e o outro grupo queria a substituição do candidato, e a velha guarda não concordou. 
O partido tinha uma Comissão Diretora de quinze membros, eleitos por acadêmicos inscritos no partido e que se encerrava com a formatura. A velha guarda era o pessoal que estava no quarto e quinto ano, e que geralmente manobrava o partido, pois era o aluno mais experiente, e havia uma disputa muito grande para ser o presidente da Comissão Diretora, o qual dava as linhas e exercia influência sobre o presidente do Centro Acadêmico, dizendo "olha é preciso fazer isso"

Todos os temas e posições partidárias eram discutidos pela Comissão Diretora e as deliberações eram encaminhadas para os membros. Dali se extraiam as próximas etapas a serem seguidas. Então o pessoal da velha guarda tomou uma posição, acabou havendo o conflito e o Renovador perdeu a eleição.

Portanto, exemplificando, no caso do Fasano, que era do Libertador, votou-se aquele problema da luta contra o Getúlio, que era uma orientação do partido dele. E houve uma participação gigantesca do Centro Acadêmico nesse episódio. O Carlos Lacerda veio na Faculdade, e todos bradavam pela renúncia de Vargas.

Depois, 1955 foi um ano mais calmo, o Luiz Carlos Pereira Barreto, que é um caso interessante porque o pai dele tinha sido presidente do Centro em 1930, José Edgar Pereira Barreto, único caso de pai e filho presidentes. Foi na Gestão do Luiz Carlos que se conseguiu o terreno, com o seu contato com o Jânio. E nós tivemos no Centro a história de dois presidentes irmãos: César Lacerda de Vergueiro e o Firmo Vergueiro. Se o mandato do Luiz Carlos Pereira Barreto fosse maior, daria para construir o campo de futebol no terreno, foi feita até a maquete, no início. Mas depois não se continuou, porque aí o Renovador não ganhou em 1956, voltou o Libertador com o Paulo e não houve continuidade, acabou não se construindo o estádio.

O estádio seria construido na área do Campo do XI, na Av. 23 de Maio?

Isso, que inclusive foi doado no período em que o Jânio Quadros foi governador. O Jânio foi de uma secretaria do XI de Agosto na época em que o Ulisses Guimarães foi $01^{0}$ orador (1939), cujo discurso está transcrito no livro. Ulisses Guimarães foi um dos grandes parlamentares de época, e presidente da mesa na Assembléia Nacional Constituinte de 1988. Mas, prosseguindo, depois disso a coisa começou a ferver em 63 e 64 . 
De fato, no início da década de 60, o clima político nacional era bastante tenso e polarizado entre os opositores ao Governo Jango e os movimentos progressistas, dentre os quais o Centro Acadêmico XI de Agosto. Os estudantes do Largo tiveram um papel fundamental na busca de sustentação politica ao governo, promovendo eventos públicos de apoio e incentivo às reformas, que encontravam visceral resistência dos setores conservadores da sociedade. Foi então que em 63 encheu-se o Salão Nobre para a posse da Gestão do XI, contando com a presença de João Goulart. A Faculdade se transformou num palco dos embates que cingiam o país. O Centro trazia para o Largo os ministros da Reforma Agrária e da Justiça, para o deleite de alguns estudantes e irritação de outros, que se opunham ao governo de esquerda.

Em 1964 tomava posse João Miguel, o qual, em 31 de Março, foi recebido por Jango e por Darcy Ribeiro (ministro da Casa Civil) em Brasilia, a fim de obter recursos para promover um evento público pela paz em São Paulo, para superar a tensão que insinuava ruptura com a Democracia. Porém, não foi possivel, pois as tropas e os tanques já ocupavam algumas capitais. De volta à capital, João Miguel foi levado aos porões do DOPS e sofreu pressão para renunciar ao XI. O Centro caiu na clandestinidade, e foi nomeado um interventor, que era o Anhaia Melo, o qual fora presidente do Centro Acadêmico em 1949. É uma contradição?

O Anhaia era uma figura muito distinta e creio que ele aceitou ser interventor para não haver o desprazer do Governo Federal acabar forçando a Faculdade a nomear um interventor de fora, um militar ou outra pessoa qualquer, o que seria terrível. Eu acho que foi uma maneira de evitar uma guerra, porque se entra um interventor que não fosse ligado à Faculdade, ao estudante, a coisa ia ser um escândalo. E o Anhaia aceitou isso penosamente, e não apresentou nenhuma hostilidade. Pelo contrário, foi um homem de modos cavalheirescos, o qual procurou num período muito difícil ir acomodando as coisas, para tentar salvar a independência do XI de Agosto, a qual estava muito comprometida e extremamente complicada. O João Miguel foi preso, teve o seu mandato interrompido...ficou um período muito ruim, ai que voltou com o Hélio em 1965.

Inclusive o Anhaia Melo foi conselheiro do Tribunal de Contas e professor da Faculdade... 
E acho que por ele ter sido presidente do Centro, a presença dele no XI foi para evitar um mal maior. Para evitar uma figura estranha, pois aí ia dar um grande problema mesmo. Os estudantes não iriam aceitar, e o Anhaia era muito discreto, um homem do Direito, foi muito respeitoso. Naquela época o diálogo era muito difícil com a escola.

Foi a época do Alfredo Buzaid e do Gama e Silva... no tempo da resistência, em 1968, com a tomada da Faculdade, em que os alunos entraram por uma passagem subterrânea que liga o porão (onde fica o XI) até o pátio. E lá colocaram tijolos nos arcos de entrada da Faculdade, a qual virou foro de discussão sobre os rumos da Universidade Pública, reforma do ensino jurídico e democratização do país. Professores como Caio Prado Jr, Rocha Barros, Dalmo Dallari faziam conferências para os alunos...

Esse foi um episódio muito bonito, porque os estudantes ficaram quase um mês aqui dentro, entrincheirados, depois acabou sendo todo mundo preso. Eles ocuparam a Faculdade em junho de 1968 e em 18 de julho, 26 dias depois, a polícia invade a Faculdade e também o Centro, levando, toda a documentação. E a situação piorou em 13 de dezembro, quando foi publicado o AI-5.

Quais foram os prejuízos que o Centro Acadêmico teve nesse período?

Houve prejuízos materiais. Simplesmente levaram tudo, carregaram todo o arquivo que eu passei anos lutando para esses palhaços devolverem aquilo que era nosso. Estava no DOPS, e você não podia ver, e devolveram, mas devolveram uma porcaria de coisa. Queimaram tudo e só devolveram meia dúzia de papéis. Encheram um caminhão com as coisas do XI de Agosto. Tinham feito isso em 1943, levaram tudo em 1943 quando morreu gente, foi o ano da primeira invasão do Centro. Foi um movimento muito grande contra a ditadura Getulista, com estudantes fazendo passeatas, aí a polícia começou a atirar. Não matou nenhum estudante, mas mataram outras pessoas. O João Brasil Vita, que é vereador, tem até hoje uma bala no pulmão que não pôde ser extraída, que é dessa época. Ficaram feridos vários estudantes e o Magano foi eleito. 


\section{Octávio Bueno Magano?}

Não, o Octávio Bueno Magano concorreu comigo, ele hoje é professor de Direito do Trabalho. O irmão dele mais velho, o Haroldo Bueno Magano, em 43, na passeata tomou um tiro na perna, e era candidato à presidente do Centro. E ele apareceu na Faculdade numa cadeira de rodas, todo enfaixado e ganhou a eleição por causa disso.

\section{Virou um herói?}

É, ele na realidade tinha sido atingido mesmo. Estava havendo uma passeata com os estudantes protestando contra o Getúlio, aí teve confronto com a polícia, o comando da polícia determinou que eles parassem. Aquela multidão de estudantes não parou, e aí começaram a atirar, morreram umas quatro pessoas, inclusive o Silva Teles, que era um estudante do Colégio, e uma senhora. No livro eu dou a relação dos mortos, sendo que dos estudantes, o Haroldo ficou com um tiro na perna, o Brasil Vita, que foi por seis ou sete vezes vereador, tomou um tiro no pulmão, só que a bala não foi extraída porque senão ele morreria. Ele tem a bala até hoje. O Brasil Vita estudou aqui e era membro do Partido Conservador.

Assim, a polícia invadiu o Centro e levou tudo, e depois voltou a levar em 68. Eu fico pê da vida, pois foram as duas vezes que levaram a documentação nossa e nunca devolveram. Perdemos todo um acervo histórico do Centro. Ficaram com os documentos como se fossem deles. Ficou tudo lá, ninguém podia ver, eu cansei de querer ir ver, não consegui e depois devolveram umas coisinhas. Em 68, após a tomada da Faculdade muitos estudantes morreram, foram para a clandestinidade, mas essa história eu não tive tempo de contar porque senão eu não terminaria a edição do livro, é uma coisa linda esse episódio, dá margens a um estudo vasto. Os estudantes foram para a clandestinidade, trocaram de nome, foram exilados.

\section{Quais foram as características que o XI sempre preservou?}

O fato de sempre haver eleição desde 1903, nas prévias, nas convenções, isso é um aprimoramento do processo democrático. É uma coisa que o Centro sempre fez e que vai aprimorando o estudante do amanhã, que vai ser um homem que leva consigo o respeito pelas minorias, o debate, a eleição, a 
Democracia. Por isso que eu digo que o Centro é uma grande escola, aqui nunca se fez trapaça, quer dizer, acho que é um exercício de ética. Você disputa, compete com o colega que concorre com a gente, isso aquilo. Octávio Bueno Magano foi meu concorrente no XI de Agosto, e sempre foi meu amigo, ele tomou um rumo na vida e eu tomei outro, isso é uma coisa espetacular, porque o XI não prepara só o advogado, envolve o culto ao Direito, ao estudo, e à arte política, que eu acredito ser importante para um país como o Brasil.

Olhe para os homens públicos americanos, a maioria saiu daquelas grandes universidades, o Kennedy... saíram das grandes universidades que estudam Direito. Essas pessoas que hoje dominam o mundo são formadas pelas grandes universidades americanas, basicamente de Direito. Também na Inglaterra, na França, foram as universidades que formaram seus grandes homens públicos. A escola é isso, a nossa escola principalmente, que é a mais importante do Brasil, uma escola que deu onze presidentes da República, a de Recife deu dois presidentes da República. Perceba, com exceção dos militares, no Brasil a maioria dos presidentes são formados aqui ou em Recife. Um ou outro tiveram outra formação, caso do Juscelino que é médico, do Fernando Henrique que é sociólogo, mas a grande porcentagem ou é de escola militar ou de estudantes de Direito. E entendo que o Centro Aradêmico deva ter uma posição voltada para os problemas nacionais.

Na nossa época a televisão era incipiente e nós fazíamos conferências aqui na Faculdade e comício em praça pública. Hoje, talvez o processo seja diferente: é o debate na televisão, com estudantes bastante preparados para fazerem bonito. E importante é o estudante fazer um curso de oratória, ter bons conhecimentos para o diálogo. Antigamente a gente convidava o povão para vir aqui e enchia a Sala dos Estudantes! É fácil notar que a televisão faz um efeito muito maior, se você tiver um time de primeira grandeza debatendo, ou sendo entrevistado, pessoas gabaritadas, não importa se a classe conservadora se posicione contra, não interessa. O que interessa é que é preciso se preparar para tomar posição sobre os grandes temas nacionais. Hoje eu acho que o pessoal está despreparado, e precisava se aperfeiçoar mais.

A Faculdade teve uma tradição de oratória. Daqui saíram grandes oradores. Basta ver que certa vez houve um concurso de oratória aqui na Faculdade e o $1^{\circ}$ colocado foi Waldir Troncoso Peres, advogado criminalista de nomeada, e em $2^{\circ}$ lugar ficou o José Gregori. 
Atualmente uma das maiores dificuldades do Centro Acadêmico é engajar politicamente os alunos, e fazer com que eles participem e colaborem mais com a atuação do C. A. Sempre foi assim?

Olha, sempre foi a minoria que mobilizou. Quando fui presidente do XI de Agosto, a Faculdade abria às oito horas da manhã, eu vinha antes todos os dias e sentava perto de um aluno, e ficava conversando com ele, para interessá-lo nos problemas. Era aluno que trabalhava e não queria perder tempo, depois veio o curso noturno. Eu vinha de manhã para assistir minhas aulas, depois vinha no curso noturno e também assistia às aulas mais para ficar com os alunos. Então, a liderança é que fazia esse trabalho de proselitismo, de conversar com o colega e interessá-lo, porque realmente há uma camada grande que não tem interesse.

\section{E isso desde o início do Centro Acadêmico?}

É, podemos afirmar que sempre foi assim. E acredito que é o estudante engajado é que tem dever de fazer esse contato com o colega e sair, e conversar, e participar... ir ampliando. E foram esses fatores que geraram esses partidos acadêmicos bem sintonizados, grandes. O Renovador tinha perto de mil associados. Como se fazia eleição de Comissão Diretora, prévias, você sempre tinha os processos eleitorais em andamento, e sempre ficava mobilizando os colegas que acábavam se interessando, participando. Na Campanha do petróleo, você mostrava para o colega que era importante ele estar lá. Então, ele ia uma vez, depois viajava um dia. Mas esse é um trabalho do líder, se não existir um líder os alunos não vão participar mesmo. Se o líder parar, a tendência é a acomodação. O mundo será sempre assim, é papel do líder fazer o contato com os colegas e jeitosamente ir mostrando, conversando a respeito dos temas, como na nossa época foi o petróleo. Esse é o lugar do líder. A Faculdade como um todo é mais estática mesmo. $\mathrm{O}$ estudante é basicamente um cidadão interessado em vencer profissionalmente, ganhar dinheiro. Você precisa de um líder estudantil, é que talvez no passado existisse mais líderes estudantis de nomeada. Eu tive colegas de grande condição. Creio no potencial dos estudantes e eles precisam treinar.

Naquela época havia mais treino, por exemplo, com a oratória?

O treino, o debate, a eleição, a eleição contínua, a eleição de uma Comissão Diretora, todo esse clima eleitoral que vai treinando o ser humano a 
expressar-se, por exemplo, contra os desmandos da ditadura. O indivíduo se educa politicamente. Então, a participação, levar um colega para participar de um debate, até a ida na Vera Cruz, em São Bernardo, para participar como figurante nos filmes, era uma forma de congregação. Você levava os colegas lá para ver o ator trabalhar. Íamos também ao teatro. Você ia sair, ia tomar cerveja, quer dizer, isso é um clima que deixa o colega atualizado, porque o pior tipo é o cara amorfo. Penso que tudo é um conjunto, é um processo eleitoral acadêmico, aí surgem os temas. Nós tínhamos muito teatro dentro da Faculdade, a gente debatia as peças dos grandes dramaturgos modernos. A oratória, o processo eleitoral, a Comissão Diretora para congregar, por exemplo, se tem um colega que pensa diferente, não importa você vai e debate, forma o seu grupo...

Esse convívio faz depois dessa escola uma grande escola, faz formar grandes advogados, grandes poetas, oradores, políticos, isso é um celeiro. E para você manter esse celeiro, não pode acontecer o que acontece hoje... a Faculdade está começando a dormir. O conjunto se faz com uma tomada de medidas, como se fez aí a luta no passado pelo fim da violência policial, pelo voto, pela eleição, pela eleição em São Paulo, que não era eleição, o prefeito era nomeado, pelo petróleo, por isso, por aquilo, nós tivemos grandes campanhas em toda a história deste século. E o XI de Agosto sempre esteve na linha de frente desses episódios. Na do petróleo, por exemplo, ele foi muito linha de frente. Os principais generais brasileiros, os principais jornalistas, os principais políticos que defendiam um mesmo tema da importância de, naquela época, haver o monopólio estavam na Faculdade fazendo conferências. Ou estavam em praça pública fazendo discurso. Eu acho todo esse conjunto de fatores muito importantes.

\section{E as campanhas eleitorais, como eram?}

A gente pregava cartazes pela Faculdade e usava uma bandinha de música, chegava a ter três bandinhas de música dentro da Faculdade de cada partido. Que é um pretexto para você reunir as pessoas, é apenas para chamar a atenção da Faculdade. E no lançamento do meu livro no dia 09 de Agosto de 1999, tem uma bandinha de música e vem gente, de acordo com o cadastro dos convites, você tem desde alunos formados em 1934, o mais antigo é de 34, depois você tem de 35, 36, $37, \ldots$ é um pouquinho de cada turma até agora. É uma homenagem que presto às várias gerações, através de alguns colegas que você escolhe para entregar o livro. É uma maneira de rememorar todo esses episódios, do que foi a escola, e do que ela 
não pode perder. Eu fico triste por ver esse materialismo muito acentuado, essa preocupação com o dinheiro, muito despropositada... a luta pela vida é uma constante em todos nós! E eu na idade que estou, estou com 75 anos e estou trabalhando ativamente. Isso é uma luta constante que você faz até morrer. Eu acho que não tem nada ver.

\section{E sobre o Chico Elefante. Você fala dele no livro?}

Eu falo dele aqui no livro... Chico Elefante foi uma figura interessantíssima, tomava conta do restaurante. Era uma pessoa queridíssima. Uma vez ele foi seqüestrado pelos estudantes numa brincadeira... eu depois posso te dar um monte de informação. Eu tive de escrever quatro, cinco linhas sobre cada um senão eu nunca iria terminar essa obra. Ele era desse tamanhinho, e tinha esse nome de Chico Elefante que era exatamente o contrário do que ele era. Ele era uma figura mirradinha. Chamava-se Francisco Ramos. Cuidou a vida toda do restaurante, depois ficou um tempo na secretaria do Centro. Aí, numa diretoria do Centro houve qualquer coisa, ele se aborreceu, e foi embora. Era funcionário do Centro... mas é dessas figuras incriveis que você não pode mexer, ninguém mexia com o Centro porque o Chico tomava conta de tudo, era muito engraçado. Ele era do meu tempo, baixotinho, magrinho. Há várias estórias sobre ele. Ele e outros Chicos ficaram muito queridos, como o Chico Emygdio que era o tesoureiro da Faculdade e foi uma figura muito querida dos estudantes, que fazia o que se chamava de mediana, ele saía com os estudantes para tomar chope. Tinha ainda o Chico Torres que era um que trabalhava no correio, era também muito engraçado, ele ficou quinze anos na Faculdade.

Agora, também tinha um Nelson Rodrigues do Largo. Era um poeta espetacular, poeta daqueles do tipo antigo, à lá Byron, trágico, bebia muito. O Chico Elefante começou como garçom na sede em que estava o prédio Martinelli, depois foi arrendatário do restaurante já na Rua Riachuelo e quando se aposentou ficou encarregado da aposentadoria administrativa. O Centro funcionou no prédio Martinelli na época da reforma da Faculdade, que foi até 34, porque não era possível ficar aqui, que foi quando a Faculdade tomou este formato que tem hoje. Então lá ele começou como garçom. Eu vim a conhecer o Chico aqui, porque daí o Centro voltou para cá. 
Agora gostaria de ir para certas incoerências e que é até curioso sobre o Alfredo Buzaid, que foi membro do Centro Acadêmico nos anos 30, fazia parte da Comissão de Sindicância (incumbia-se de quem ia ou-não ser sócio do XI), e que depois em 68 foi o diretor da Faculdade que perseguiu estudantes, e o Gama e Silva (redator do AI-5) que foi paraninfo da turma em que o Almino Afonso foi o orador.

Bom, prefiro não falar nada, o Buzaid e o Gama e Silva são homens ligados à ditadura. Mas o Gama e Silva ficou chato depois, na época em que eu era estudante e ele foi paraninfo ele era livre docente e era legal. A postura dele era outra. Depois começaram a servir o governo da ditadura. O Buzaid era um homem de grande cultura, mas isso aí eu prefiro não falar porque é uma coisa muito triste. A postura deles foi triste.

A impressão que fica é a de que, embora eles tenham sido homens do Direito, não titubearam em servir ao Poder, e cometeram decisões contrárias à liberdade de pensamento do País.

Você veja no Tribunal de Nuremberg, aquele ministro da Justiça da Alemanha que foi condenado, ele era um homem do Direito de uma grande Universidade Alemã, mas foi servir ao Hitler, acabou que ele assinava o envio de gente para o campo de concentração e para as câmaras de gás. E em Nuremberg, até passou um filme retratando esse episódio, o julgamento é presidido por um juiz americano, que é fato real. E o tal ministro estava na condição de réu, e tentava se justificar dizendo que foram poucas as condenações que ele havia assinado. Porém o juiz disse "bom, mas o senhor é um jurista, a primeira que o senhor fez já é motivo para a condenação." Um advogado brilhante, e um grande jurista acaba sendo ministro no Governo do Hitler, e passa a perseguir judeus, quer dizer, ele saiu da posição dele. Então, penso que um homem da Faculdade de Direito que vai seguir um governo de ditadura não pode aceitar um cargo desse. Você vê, várias pessoas não aceitaram ser ministro da Justiça do Governo Fernando Henrique, ele havia convidado cinco pessoas, o quinto é que aceitou.

Mas o meu livro é um livro de amor. Uma vez me perguntaram porque eu não escrevia sobre o professor Reale, e eu falei "não, meu livro é um livro de amor pela Faculdade, não é um livro para ficar falando de pessoas que tiveram tal ou qual atitude na sua vida. Isso não é o que eu me propus" Eu me propus a um 
livro que mostre a pujança de um Centro Acadêmico, o que pode fazer um estudante de Direito, bem direcionado para sua pátria, estar bem preparado para ser útil, aí falam "você pulou o episódio aí!" Eu pulei o episódio propositadamente, não quero abordar. Mas esses homens da ditadura, é importante os alunos do Centro Acadêmico estarem atentos a isso, e saberem que um homem do Direito não deve servir a este tipo de coisa.

Meu livro é um hino de amor à Faculdade, ao Centro Acadêmico em especial, uma pesquisa que eu levei onze anos.

\section{O que significa para o senhor o Centro Acadêmico XI de Agosto?}

Significa tudo, é a coisa mais importante da minha vida. Apesar de eu ter ocupado outros cargos no Governo, fui presidente nacional do IAPI, fui presidente da Empasa... o IAPI era o Instituto Nacional de Aposentadoria e Pensão, porque a previdência social era separada em institutos, eram seis institutos, o maior deles era o IAPI que era dos trabalhadores da indústria, no Governo João Goulart, que foi na minha opinião um grande Governo. O Almino foi o ministro, então você tinha a possibilidade de um governo que estava voltado para o povo, você tinha possibilidade e condição de fazer um trabalho gostoso com uma pessoa que está num cargo público, que gosta de fazer. Eu viajava por esse Brasil afora com o Almino, com essa preocupação. Então, é gostoso você estar num governo em que as coisas são vistas do mesmo jeito que você gosta, você trabalha sem ser pedante, besta, metido à intelectual, nada disso. O Jango era um cara prático, um sujeito voltado para o trabalhador, e a presença dele aqui na Faculdade em 1964 foi uma maravilha, foi uma integração do Governo com o estudante do XI de Agosto, nunca na história do XI de Agosto um presidente da República veio à posse de um presidente humilde do Centro, um mulato, filho de uma lavadeira, uma coisa que sempre me emocionou muito. O Janga fez questão de assistir à posse de um presidente do XI de Agosto. Então você veja a dimensão que existia para um Jango que era da família Vargas e que tem o sangue na política e que é advogado. $O$ Getúlio e o Jango são advogados formados em Porto Alegre, e o Getúlio foi o orador da turma. A gente precisa também ver este contexto.

O Getúlio ficou muito marcado por São Paulo por causa desse problema da Revolução, de toda a luta de São Paulo. Mas ele era um homem voltado para o trabalhador, você veja que a Consolidação das Leis do Trabalho foi feita pelo Getúlio, e o ministro dele era um parente meu, Marcondes Filho, um homem do 
Direito formado aqui na São Francisco. Um homem que trabalhou para o Vargas, mas cuja atuação foi voltada para o trabalhador, por isso que eu digo, não é condenável o fato de trabalhar com o ditador, é preciso analisar qual tipo de trabalho, sujeito está fazendo. Fazer um trabalho do Direito voltado para a legislação trabalhista a favor do trabalhador é uma coisa, agora você fazer um ato que desrespeite a natureza do ser humano é diferente. Por isso afirmo que um homem do Direito tem de ter uma postura digna. Mesmo trabalhando com o Getúlio, ele foi um homem estritamente do Direito do Trabalho, para a legislação trabalhista, sempre com essa preocupação.

De qualquer forma, a coisa de que mais me orgulho na vida é ter sido Presidente do XI de Agosto, e as campanhas que eu fiz, a luta pelo petróleo, conheci pessoas maravilhosas, extraordinárias, preocupadas com o Brasil, não preocupadas com o sucesso pessoal, com dinheiro, são figuras incriveis que você acaba conhecendo e vendo que há muita esperança. Agora, o pior é quando você vê o jovem amolecer, esse é um mal sinal. Que o velho amoleça você ainda aceita, mas o jovem não.

Qual a mensagem o Sr. deixa para as próximas gestões do XI? Praticamente o XI já vai completar 100 anos, em 2003.

Resumindo, o XI de Agosto precisa estar sempre preocupado com os problemas nacionais. Penso que ele tem sempre de transmitir uma mensagem aos jovens independentemente da escolaridade, seja dentro da UEE, dentro da UNE. O estudante de Direito tem uma obrigação, referente a sempre procurar liderar os movimentos, e ter uma postura muito correta. Porque ele é um estudante de Direito, sabe o que é o certo, mas deve aprender a ter uma postura avançada, pois no meio dos estudantes em geral é ele que deve abrir esse caminho.

O líder estudantil aqui dentro da Faculdade, esse tem uma missão muito nobre. É ele que está destacado, na liderança, e não importa se a grande maioria encontra-se acomodada, isso vai existir sempre. E a motivação do estudante tem de vir dele mesmo, ele tem de participar, tem que debater. Hoje temos um instrumental diferente, mas muito melhor, muito mais fácil até. $\mathrm{O}$ estudante de Direito é muito importante, não pode ficar enclausurado só nos problemas voltados para o ensino, que também é relevante. Mas ele tem uma missão.

E Roger Ferreira, o qual foi vereador, deputado federal, dizia que a coisa de que ele mais se orgulhava na vida era ter sido presidente do XI de Agosto. 
Porque é aqui que você abre a sua cabeça, faz com que você participe. Considero o Roger como um dos grandes líderes que eu conheci na minha vida. Participar da diretoria do XI de Agosto, não só pelo fato de ser presidente, sendo um diretor do $\mathrm{XI}$, tendo uma participação ativa na política acadêmica, isto é fundamental.

Essa atividade prepara o jovem para ter gestos que transformem 0 País. Mesmo que não seja na política. O país precisa demais dos bons estudantes de Direito. Para o estudante de Direito no século XXI eu almejaria isso. Não queria morrer sem ver o XI de Agosto numa posição de destaque, mesmo que ele tenha um envolvimento com partido político, este tipo de envolvimento não tem importância, mas eu acho que ele tem de debater.

Eu fui estudante, filiei-me a partido político, porque desde garoto tinha as minhas conviç̧ões de esquerda. Mas isso não importa, tive grande amigos que divergiam de mim mas que deram grande contribuição porque eram estudiosos, tinham liderança, participavam dos debates, uns mais voltados para o teatro, outros mais para a oratória, esse conjunto de coisas, de participação do estudante que lidera este movimento, é que faz o perfil do XI de Agosto, que é para mim um perfil grandioso.

É por isso, sem querer ser muito repetitivo, só para enfatizar, que você compreende porque um presidente da República venha à posse de um presidente do Centro Acadêmico XI de Agosto. Você um dia vai ver como é importanté isto, porque o Jango demonstrava um profundo respeito pelo estudante da São Francisco. Ele sabia que São Paulo era um Estado pujante, onde havia uma Faculdade de nomeada, de primeira linha, com todos os seus defeitos, mas uma Faculdade no contexto universitário muito importante. Mas não tenha dúvida, é sempre um grupo menor de interessados dentro do pátio. Mas é esse grupo menor que dá o perfil. A minha esperança é que o XI de Agosto seja melhor do que no meu tempo!

\section{Há 97 Anos... 1903: Ano de Fundação}

"Art. 1. Sob a denominação de Centro Acadêmico XI de Agosto, fica fundada uma associação de alunos matriculados na Faculdade de Direito de São Paulo.

Esse é o começo do primeiro estatuto do Centro Acadêmico XI de Agosto publicado a 19 de agosto de 1903, e que sintetiza a concretização do sonho e do esforço de alguns estudantes da época. Foi possível a formação do XI graças às 
diversas reuniões envolvendo acadêmicos interessados em reunir todos os estudantes de Direito das Arcadas sob a mesma bandeira.

Não foi tarefa fácil, pois (como hoje) havia céticos e indiferentes à idéia, que duvidavam do sucesso de tal empreendimento e que afirmavam palavras de descrédito e desânimo pelo espírito associativo acadêmico. Mas aqueles convictos na idéia de criação do Centro não lhes deram ouvidos, e foi então que numa sessão em que estavam presentes grande parte dos alunos da Faculdade, num clima de cordialidade e entusiasmo, escolheu-se as pessoas incumbidas de elaborar os estatutos do Centro: Pedro Dória, Luiz Pereira de Campos Vergueiro e Macedo Soares.

Após três meses para redigir, discutir e aprovar os estatutos, convocou-se a reunião para se eleger a primeira diretoria da associação que devia representar todos os acadêmicos. A eleição da primeira diretoria, extremamente concorrida e que legitimou o entusiasmo geral, deu o seguinte resultado:

$\begin{array}{ll}\text { Presidente: } & \text { Pedro Dória } \\ \text { Vice-Presidente: } & \text { Marcello Francisco Silva } \\ 1^{\circ} \text { Secretário: } & \text { Fausto de Barros Camargo } \\ 2^{\circ} \text { Secretário: } & \text { Amadeu Gomes de Souza } \\ 1^{\circ} \text { Orador: } & \text { José de Paula Rodrigues Alves } \\ 2^{\circ} \text { Orador: } & \text { Pedro Soares de Sampaio Dória } \\ \text { Tesoureiro: } & \text { Fernando Pacheco Chaves } \\ \text { Procurador: } & \text { Eliezer Arouche de Toledo } \\ \text { Comissão de Redação: }\end{array}$

Armando Rodrigues

José Bento Monteiro Lobato

Lino Moreira

Paulo Galvão Sampaio

Comissão de Sindicância:

Guilherme Vallim Álvares Rubião

Pio de Almeida Prado

Polycarpo de Magalhães Viotti

Todos os eleitos tiveram quase unanimidade na votação. Os fundadores do XI de Agosto pensaram que a data 11 de agosto, que assinala a fundação dos Cursos Jurídicos brasileiros, devia ficar como um símbolo. $\mathrm{O}$ mesmo 
nome foi dado à sua Revista, que ainda hoje se publica. E aguardaram o dia 11 de agosto para a instalação oficial da nova associação acadêmica.

A 11 de agosto de 1903, em uma sessão solene, a primeira que se fazia à noite na Academia, onde, então, não havia luz elétrica, instalou-se o Centro Acadêmico XI de Agosto. Para que se realizasse a sessão, foi necessário que se fizesse uma instalação provisória de luz elétrica.

A sessão inaugural foi presidida por Pedro Dória, sentado entre dois dos maiores vultos que têm iluminado a cátedra da Academia de São Paulo: Pedro Lessa e João Pereira Monteiro. Nessa sessão viam-se representantes de todas as autoridades constituídas do Estado, além das principais famílias paulistanas.

A gestão de Pedro Dória enfrentou dificuldades para consolidar o Centro. Por exemplo, era exigida uma mensalidade para tornar-se sócio: em regra 0 estudante tem horror a tal espécie de contribuição.

Pedro Dória não tinha perfil agressivo e arrebatador; era calmo, ponderado, e aos poucos foi reunindo em torno do Centro a maioria dos seus colegas. E pôde, ao final de seu mandato, deixar o XI de Agosto como uma organização vitoriosa. Seus companheiros de diretoria também trabalharam com afinco, entre eles José de Paula Rodrigues Alves, o qual veio a ser embaixador do Brasil na Argentina, e Amadeu Gomes de Souza, posteriormente deputado estadual e presidente da Companhia Mogiana de Estradas de Ferro.

Cumpre aqui destacar a figura de um moço de excessiva modéstia, quase um desconhecido para os seus colegas: José Bento Monteiro Lobato, o autor de Urupês. Foi Pedro Dória quem lembrou o seu nome para a redação da Revista $O$ Onze de Agosto, que se começou a editar nesse ano. Monteiro Lobato principiou, então, a sua carreira de escritor. Logo de início ficou conhecido e admirado pelos seus colegas de bancos acadêmicos. Era a revelação de um grande escritor.

No editorial que abre a edição n. 1 da Revista $O$ Onze de Agosto estabeleceu-se os objetivos para o brilho da nova associação: "(...)E marcando, talvez, o início do ressurgimento completo do antigo esplendor da vida acadêmica, forma-se agora o Centro Acadêmico XI de Agôsto, que, procurando formar verdadeiros combatentes para as lutas, em prol dos interesses da sociedade brasileira, busca, ao mesmo tempo, tornar mais amena a vida acadêmica, derruindo por completo as barreiras que parecem existir entre os estudantes dos diversos annos do curso jurídico, e fazendo de cada estudante, sem distinç̧ão de especie alguma, o seguinte: um acadêmico. 
No início a sede do Centro ficava à esquerda de quem entra para o pátio, onde veio a ser a Sala de Armas, do Tiro de Guerra da Faculdade. Depois a sede foi transferida para uma sala do centro da cidade. Ficava no andar superior do prédio onde se localizava o Café Guarani, que era, então, o ponto predileto de reunião dos estudantes.

Ocorreu ainda em 1903 um episódio memorável: a chegada de Santos Dumont $^{1}$ ao Brasil, com a realização de grande recepção no Rio de Janeiro, a então capital do País. O XI conseguiu do Governo da República um trem especial que transportou pela linha Central do Brasil, a qual liga São Paulo ao Rio, os estudantes de Direito que iriam fazer parte da recepção. Mais de 500 acadêmicos de São Paulo foram prestigiar Santos Dumont, o grande inventor e pai da aviação.

Como era de hábito, os estudantes mandavam telegramas para as estações de trem avisando sua chegada. Mas como também era hábito não pagar a conta de suas refeições, só encontraram estabelecimentos fechados durante a viagem. Assim, depois da estadia no Rio, os acadêmicos arquitetaram um plano: enviaram um telegrama a Taubaté avisando que Santos Dumont passaria pela cidade e que chegaria no trem no qual viajavam os 500 acadêmicos "mortos de fome" Taubaté, em poucas horas, transformou-se em outra cidade: as aulas foram suspensas, sinos tocando, políticos nervosos, oradores com discurso na mão, fartura de comida e de bebida. Ao som do Hino nacional, seguido de foguetes, Santos Dumont finalmente desceu na estação da cidade, carregado pelos prestativos alunos da Faculdade de Direito. Na verdade, o pai da aviação estava encarnado na figura do acadêmico Pedro Motta que, com o seu boné de casimira, seu bigodinho e com tudo o mais numa semelhança perfeita, representava aos olhos taubateanos a pessoa de Santos Dumont. Os são-franciscanos devoraram a comida e se embebedaram de champanha. E quando o trem já estava em marcha, um estudante delatou a farsa. Entretanto, ao invés de revolta, a cidade de Taubaté transformou a homenagem a Santos Dumont em uma verdadeira festa para os acadêmicos do Largo.

1. Em 1901, perante uma Comissão do Aeroclube da França, Santos Dumont conseguiu elevar-se do solo e realizar o percurso de Saint-Cloud à Torre Eiffel, contorná-la e voltar ao ponto de partida, pilotando um balāo alongado em forma de charuto com motor a petróleo, que havia idealizado. Com isso, assegurou a dirigibilidade dos balões e arrebatou o prêmio Deutsch de La Meurthe. (Microsoft, Enciclopédia Encarta 99 ). 


\section{Associados do XI que se tornaram governantes}

Nestes 97 anos de vida, do quadro associativo do XI saíram personalidades que tomaram cargos expressivos, dentre os quais temos três presidentes da República, um presidente do Estado, sete governadores, três interventores estaduais, quatro vice-governadores e cinco prefeitos da Capital. São eles:

presidente da República: José Linhares

Nereo de Oliveira Ramos

Jânio da Silva Quadros

presidente do Estado: Júlio Prestes de Albuquerque

governadores: Henrique Smith Bayma

José Joaquim Cardoso de Mello Neto

Jânio da Silva Quadros

Carlos Alberto Alves de Carvalho Pinto

Roberto Costa de Abreu Sodré

José Maria Marin

André Franco Montoro

interventores: José Joaquim Cardoso de Mello Neto

Sebastião Nogueira de Lima

José Carlos de Macedo Soares

vice-governadores: Manoel Gonçalves Ferreira Filho

José Maria Marin

Almino Monteiro Álvares Affonso

Aloysio Nunes Ferreira Filho

prefeitos da Capital: Goffredo Teixeira da Silva Telles

Paulo Lauro

Linneu Prestes

Jânio da Silva Quadros

William Salem 


\section{Aspectos do XI Hoje}

Nos anos 70, a ditadura militar praticamente sufocou o Centro Acadêmico e sua capacidade de expressão, sendo a época da censura e do período em que o XI cai na clandestinidade. Foi na década de 80 , com a campanha das Diretas Já em 1984, na fase de redemocratização do País, que o XI renova-se e é possivel a publicação do Estatuto até hoje vigente, e que rege a estrutura de funções de cada um dos diretores do Centro.

A novidade é que a diretoria do XI passa a ser feita por chapa completa. Junto com a diretoria é eleito um conselho fiscal independente, com a função de fiscalizar as finanças e manter a transparência do caixa da entidade. Desde então, ocorrem algumas peculiaridades quanto à eleição do Centro Acadêmico. Antigamente, os presidentes eram predominantemente alunos do $5^{\circ}$ ano. Hoje, os presidentes são do $3^{\circ}$ e do $4^{\circ}$ ano. Antes, os presidentes elegiam-se no quinto ano, pois se entendia que era melhor não estar na Faculdade sujeito a críticas sobre sua gestão, e voltar a ser um aluno "normal" Outro fato interessante é que as chapas, ao invés de ter uma estrutura moldada de acordo com o estatuto, preferem ter uma estrutura diferente. Por exemplo, na executiva as atribuições do presidente são distribuídas entre três coordenadores.

No final dos anos 80 e na década de 90 , o XI manifestou-se durante fatos que mexeram o País. A Sala dos Estudantes tornou-se local público para que o povo pudesse apresentar e ter acesso aos projetos no período da Assembléia Nacional Constituinte. Em 1992, foi às ruas exigir o impeachment de Fernando Collor. Promoveu campanhas pela democratização dos meios de comunicação, pela ética na política, por "1964 Nunca Mais" pelo fim da Justiça Militar, pelo ensino público, gratuito e de qualidade, pela Reforma Agrária, pelo desarmamento contra a violência, pela consciência política, pelos Direitos Humanos.

É importante destacar a Campanha Sou da Paz, de repercussão em todo o país, nascida por iniciativa do Centro Acadêmico XI de Agosto em $1997 \mathrm{e}$ que até hoje é um símbolo pela idéia de que ser dono de uma arma aumenta as chances de você ser morto. Destaque também para o Centro de Estudos em Direitos Humanos criado pelo Centro Acadêmico em 1998, do qual participaram políticos, estudantes de várias faculdades, membro de ONGs, que lutam pela defesa dos Direitos Humanos. O curso é ligado à cátedra da UNESCO para a paz e ao Instituto de Estudos Avançados da USP 
Na questão do acesso à Justiça é necessário destacar o trabalho do Departamento Jurídico XI de Agosto, onde os alunos prestam Assistência Jurídica gratuita à população carente, há 81 anos. O DJ, como carinhosamente é chamado, foi fundado em 19 de setembro de 1919 com o nome de Assistência Judiciária Acadêmica, e idealizado por Alcyr Porchat ( $1^{\circ}$ orador do XI em 1920).

Além disso, o Centro Acadêmico mantém um Cursinho preparatório para vestibular para aqueles que não têm condição de pagar altas mensalidades.

Ainda hoje existe a Casa do Estudante, na Avenida São João, a qual foi um dos notáveis empreendimentos do Centro Acadêmico. A sua construção foi financiada, em boa parte, com a arrecadação obtida nos famigerados Bailes da Américas, realizados anualmente em 12 de outubro. A Casa levou 11 anos para ser construída (1937 - 1948).

Outrossim, o XI possui departamentos específicos para tratar de diferentes questões. Há o de Imprensa, que cuida das publicações; o de Ensino, que trata das questões referentes à qualidade de ensino na sala de aula; Cidadania, que cuida das questões políticas; e Cultural o qual incumbe-se das festas, das Peruadas, dos ofícios do Pindura, de eventos culturais, etc.

Nos últimos cinco anos três grupos foram gestão do XI: Rasgando o Verbo (1995), Partido Acadêmico Autônomo (1996, 1997. 1998) e Grupo Ruptura (1999).

Podemos afirmar que a influência política do XI tenha enfraquecido recentemente devido à multiplicação de entidades e dos movimentos sociais. Por ele há quem sinta o compromisso e a latência dos ideais próprios do acadêmico. Embora os jovens sejam inexperientes, eles compensam isso com os sonhos de transformação da realidade, e a capacidade de enxergar novos horizontes com o brilho no olhar. Isso permeou a criação do Centro Acadêmico e continua a fascinar aqueles que dele participam.

Para encerrar, transcrevemos uma trova que até hoje se canta:

Quem entra na São Francisco

Tem mais amor à verdade,

Pois leva sempre no peito

A chama da Liberdade!

São Paulo, janeiro de 2000. 
Bibliografia:

MACHADO JR., Armando Marcondes. Centro Acadêmico XI de Agosto Faculdade de Direito de São Paulo (1903 - 1998), Ed. Pannartz (SP) 5 volumes, 1999.

DULlES, John W. F. A Faculdade de Direito de São Paulo e a Resistência AntiVargas, Edusp, 1984.

Discurso proferido por Armando Marcondes Jr. Ao receber o Prêmio XI de Agosto de 1996.

NOGUEIRA, José Luiz de Almeida Nogueira. A Academia de São Paulo Tradições e Reminiscências, Ed. Saraiva, 1977, 5 volumes.

VAMPRÉ, Spencer. Memórias para a História da Academia de São Paulo, Instituto Nacional do Livro, $2^{\text {a }}$ ed., 1977, 2 volumes.

MALHEIROS, Lauro. Rosas de Inverno, 1987.

VIEIRA, Cícero Augusto. Casa do Estudante, Coleção XI de Agosto, 1942.

VIDIGAL, Geraldo. O Aprendiz de Liberdade, Ed. Saraiva, 1988.

REZENDE, Carlos Penteado de. Tradições Musicais da Faculdade de Direito de São Paulo, Ed. Saraiva, 1954.

GIOIELLI, Sidney. Os Filhos Joviais de São Francisco, 1992.

MARTINS, Ana Luiza e BARBUY, Heloísa. Arcadas: História da Faculdade de Direito do Largo de São Francisco 1827-1997.

REALE, Ebe. Faculdade de Direito do Largo de São Francisco, A Velha e Sempre Nova Academia, Ed. Saraiva, 1997.

Agradecimentos.

Agradeço a todos os que colaboraram direta ou indiretamente para a elaboração deste artigo: Antonio Augusto, do Serviço Técnico de Imprensa, Waldir e Marilene, do Arquivo da Faculdade, ao Centro Acadêmico XI de Agosto, e à Revista "O Onze de Agosto" Obrigado. 